\title{
O Brasil desbravado: olhares cartográficos e interpretaçóes do país
}

\section{Pedro Campos Franke}

KNAUSS, Paulo; RICCI, Claudia; CHIAVARI, Maria Pace. Brasil: uma cartografia. Rio de Janeiro: Casa da Palavra, 2010.

Apesar de uma série de trabalhos de pesquisa que buscaram, neste século e no último, trazer a cartografia a um debate historiográfico interessado não apenas nas evoluções técnicas e na precisão das representaçôes geográficas, mas também na concepçáo dos mapas como indicadora de aspectos políticos e culturais dos agentes históricos, o campo da história da cartografia ainda encontra à sua frente um amplo caminho a ser percorrido na historiografia brasileira. Pensados como construçóes intelectuais complexas, os mapas podem lançar novos olhares sobre expressóes culturais, demandas políticas e anseios sociais de seus diferentes momentos e espaços históricos. Neste sentido, inestimáveis contribuiçôes à história da cartografia brasileira foram desenvolvidas no século passado por pesquisadores como Jaime Cortesão, Alfredo Pinheiro Marques e Norma Abreu Telles.

O livro Brasil: uma cartografia procura somar esforços a este âmbito historiográfico com uma formidável lista de reproduçóes - não apenas de mapas históricos, mas também de obras de arte que remetem direta ou indiretamente ao campo da cartografia - e com um sólido suporte textual dirigido, tanto aos pesquisadores da área, quanto a um público interessado mais abrangente. $\mathrm{O}$ que se faz evidente, desde a introdução até o último capítulo do volume, é o ímpeto de contar uma breve história do Brasil através dos mapas, com uma abordagem que se apropria de contribuiçôes teóricas de três campos de pesquisa tradicionalmente distintos: a história da ciência e da técnica, a história da arte e a história intelectual. Desta última, origina-se a interpretação que procura articular à confecção dos mapas suas demandas es- pecíficas, estejam estas associadas aos anseios político-econômicos da Coroa portuguesa ou do Estado nacional, ao simbolismo religioso ou à estratégia militar.

A disposição dos capítulos, ainda que possa indicar uma narrativa cronológica, em termos gerais, remete às diferentes percepçóes espaciais do território brasileiro. Assim, a primeira parte trata das representaçóes cartográficas do Brasil, a partir do mar, e abrange todo o período inicial das grandes navegaçóes e das disputas dos territórios litorâneos pelas naçóes europeias; em seguida, trata-se da exploraçáo do interior do continente, do mapeamento dos rios e do reconhecimento das fronteiras nacionais à época do Império; por fim, são examinadas as cartas do país elaboradas a partir do espaço aéreo - desde os primeiros desenhos produzidos em voos de balóes, no contexto da Guerra do Paraguai, até as modernas imagens de satélites.

Nos comentários às cartas geográficas da primeira fase da colonização portuguesa da América, os autores ressaltam a presença constante de elementos narrativos que fogem à mera representação topográfica da costa, consubstanciados nas ilustraçóes representando os costumes nativos, a extração de pau-brasil, o exotismo da fauna e flora locais, ou mesmo os movimentos das tropas nos embates entre portugueses e holandeses ou franceses (a produção cartográfica destes últimos, quando de suas presenças em território brasileiro, também é devidamente contemplada). É precisamente nestes aspectos extra-geofísicos dos mapas que o trabalho deixa transparecer uma abordagem cara à história intelectual, ao interpretar a produção cartográfica como manifestação destinada a uma ou mais formas de intervenção social por aqueles que patrocinam e encomendam as cartas - na maioria dos casos as coroas europeias envolvidas na exploraçáo dos novos 
territórios. Chama-se atenção, por exemplo, para as marcaçóes dos fortes reconquistados dos franceses pelas forças luso-brasileiras no Pequeno atlas do Maranhão e Grão-Pará, de 1629; ou para os modelos cartográficos renascentistas do atlas Cosmographie Universelle, de meados do século XVI, que traz representaçôes dos povos nativos associadas ao imaginário bíblico do paraíso terrestre. Igualmente representativa desta perspectiva é a comparação entre dois mapas da costa brasileira com modelos cartográficos idênticos - um holandês, original, que se limita aos elementos geográficos, e outro italiano, baseado no primeiro, mas carregado de alegorias barrocas e referências às armas e ao brasão de Portugal. Seja na legitimação das conquistas militares, seja na reprodução do simbolismo religioso, trata-se de identificar nestas publicaçôes alguns aspectos importantes referentes aos olhares dos sujeitos históricos e à pluralidade de seus objetivos.

O estabelecimento de povoaçóes, a partir de 1530 , e a movimentação em direção ao interior do continente são postos em uma perspectiva cartográfica no segundo capítulo do livro. Pode-se perceber, então, como os espaços antes indeterminados ou preenchidos por animais exóticos e cenários bíblicos, ganham gradativamente contornos mais definidos - rios, serras e até os territórios das principais nações indígenas passam a figurar nas cartas. As capitanias hereditárias, antes delimitadas pelas linhas retas das latitudes, ganham contornos adaptados à geografia física do território, como se pode perceber numa reprodução do Nova et Accurata Brasiliae Totius Tabula - atlas holandês de Joan Blaeu, publicado em 1689, que hoje integra o acervo da Biblioteca Nacional do Rio de Janeiro. Os autores identificam, ainda, através da dinâmica das cartas, um interesse cada vez mais pragmático no mapeamento dos territórios interioranos, uma atenção voltada ao curso dos rios e à topografia das terras, conforme o foco do empreendimento colonial passa a se concentrar mais na exploraçáo do ouro e das pedras preciosas, e no escoamento de tais produtos para os centros portuários.
A relação entre a cartografia e a diplomacia constitui outro ponto forte de Brasil: uma cartografia. Sáo salientados, com justiça, os trabalhos dos padres jesuítas matemáticos Diogo Soares e Domingos Capassi que, em meados do século XVIII, viajaram pelas regiōes fronteiriças do Rio Grande do Sul, Goiás e Mato Grosso colhendo informaçóes sobre a regiáo sertaneja - agora baseadas nas inovaçóes referentes à observação das longitudes -, que serviram de base para a ação do diplomata nascido na América portuguesa, Alexandre de Gusmão, no âmbito do debate sobre os limites dos domínios coloniais.

Da diplomacia dos tempos coloniais à afirmação do Estado nacional no século XIX, a cartografia figura como elemento indispensável às grandes questôes políticas. Nos tempos do Império, as inovaçóes técnicas, no âmbito das artes gráficas, e a implantação do Arquivo Militar do Rio de Janeiro trouxeram uma nova dinâmica à produção cartográfica no país. Cada vez mais associada ao universo militar, a cartografia passa a contar com a perspectiva privilegiada dos voos de balóes durante a Guerra do Paraguai. Neste contexto, o livro reproduz a extraordinária gravura intitulada Vista geral do theatro da guerra, produzida pelo aeronauta americano James Allen, e um mapa da batalha de Tuyuty, elaborado exclusivamente a partir de vistas aéreas.

A aceleração das inovações técnicas da aerofotogrametria, acompanhada por avanços institucionais, como a criação do Instituto Brasileiro de Geografia e Estatística - já no primeiro governo Vargas -, marca a cartografia da primeira metade do século XX. Os autores ressaltam a intensa articulaçáo, a partir das grandes guerras mundiais e depois com o advento dos satélites espaciais, durante a Guerra Fria, entre a cartografia e os recursos estratégicos.

Ao final do volume, Knauss, Ricci e Chiavari trazem sua breve história da cartografia ao centro das atuais discussóes políticoambientais sobre o monitoramento das fontes naturais e do aproveitamento dos solos, em um movimento que abandona gradualmente a cen- 
tralidade da questão dos limites de fronteira e da conquista de territórios, passando a se concentrar no levantamento de informaçóes concernentes ao controle ambiental e à gerência social dos recursos naturais. A conclusão sobre os usos cotidianos da tecnologia cartográfica, entretanto, limita-se à enumeração e à descrição das facilidades técnicas do GPS (Global Position System), constituindo-se, provavelmente, no ponto mais fraco da obra.

Se o texto de Brasil: uma cartografia parece incorrer numa relativa superficialidade na articulação entre a produção cartográfica e a conjuntura política e social, isto se justifica pela abrangência de seu recorte temporal, de seus objetivos e, sobretudo, pela intenção divulgadora da publicação. De qualquer forma, a riqueza e a variedade das reproduçóes gráficas e os comentários a elas aduzidos já justificam a pertinência da publicação. Soma-se a isto a qualidade inerente a todas as boas visóes panorâmicas de um dado campo historiográfico, que sugerem novos objetos de pesquisa e inspiram novas abordagens de temas já tratados pela historiografia. 